\title{
Efficacy of Oxalic Acid and Apiguard Against Varroa Mites in Honeybee (Apis mellifera) Colonies
}

\author{
A. GREGORC \\ Agricultural Institute of Slovenia, Ljubljana, Slovenia \\ Received November 15, 2004 \\ Accepted June 6, 2005
}

\begin{abstract}
Gregorc A.: Efficacy of Oxalic Acid and Apiguard Against Varroa Mites in Honeybee (Apis mellifera) Colonies. Acta Vet. Brno 2005, 74: 441-447.

This trial assessed the comparative efficacy of oxalic acid solution (OA), which consists of $2.9 \%$ oxalic acid and $31.9 \%$ sugar in water, and Apiguard, a thymol gel, in controlling the honeybee mite Varroa destructor. In comparison with untreated control colonies, mite mortality, which was evaluated throughout the pre- and post-treatment periods, increased significantly $(p<0.001)$ in both Apiguard and OA treated colonies. The mite mortality after two Apiguard applications, on August 7 and 21, was $41.98 \%( \pm 21.59)$ and was $42.63 \%( \pm 25.22)$ after three OA applications, on August 7, 14 and 21. All applications were given to colonies with brood. Further three OA treatments conducted during October, on previously untreated control colonies, resulted in mite mortality of $87.92 \%( \pm 12.66)$. However, these levels of mite reduction were insufficient for all colonies to survive the winter. The results indicate that OA and Apiguard are of limited use during periods with brood. The possible use of OA and Apiguard against the varroa mite in honeybee colonies is discussed in this study.
\end{abstract}

Varroa destructor, thymol, mite control, pathology, treatment

Colonies with Varroa destructor (Anderson and Trueman 2000), an economically significant external parasite of honeybees, have to be controlled in order to preserve the host colony. In many countries the mites have developed a resistance to coumaphos, amitraz and pyrethroids, which are employed in most of the commonly used treatments (Lodesani et al. 1995; Milani 1999; Miozes-Koch et al. 2000; Floris et al. 2001). The use of organic substances in controlling the varroa mite has promise and is a highly desirable alternative to chemical controls as it avoids mite resistance and leaves far less residue in the hive products (Wallner 1999). The use of oxalic acid (OA) as a means of controlling varroa mite infestations in colonies has been studied extensively (Gre gorc and Planinc 2001; 2003). The efficacy of three OA treatments in colonies with brood ranged between $39 \%$ and $52 \%$ and was $99 \%$ in a broodless period. It has been found to be effective in controlling the varroa mite in honeybee colonies in a variety of climatic conditions (Brødsgaard et al. 1999; Nanetti et al. 1995).

Several products containing thymol are available and a number of experiments have been conducted to evaluate their efficacy (Gregorc and Jelenc 1996; Imdorf et al. 1999). Thymol, which is a volatile monoterpenoid, is a natural constituent of thyme (Thymus vulgaris) and is toxic to varroa mites (Lindberg et al. 2000). It has been established that $1.1 \mathrm{mg}$ thymol/ $\mathrm{kg}$ honey or less will not affect the taste of the honey and that when applied following the harvest its residues, which are not persistent, do not occur above levels found naturally in honey (Bogdanov et al. 1998). Natural acaricides are a highly desirable alternative to synthetic products. Thymol treatments can be used in place of chemical treatments such as coumaphos and amitraz. However, only one registered thymol-based acaricide was used to evaluate the efficacy of thymol as a control for the varroa mite. Apiguard consists of thymol released gradually from a food-grade gel.

\footnotetext{
Address for correspondence:

Dr. A. Gregorc

Agricultural Institute of Slovenia

Hacquetova 17

SI-1000 Ljubljana, Slovenia
}

Phone: +38612805150

Fax: +38612805255

E-mail: ales.gregorc@kis.si

http://www.vfu.cz/acta-vet/actavet.htm 
The primary objective of our field experiment was to evaluate and compare the acaricidal efficacy and the mite-mortality dynamics of thymol and OA treatments on honeybee colonies in central Slovenia. Another objective of this study was to compare the efficacy of Apiguard and OA treatments in controlling the varroa mite during the brood period.

\section{Materials and Methods}

The study was conducted at the Institute Beekeeping Experimental Station located in central Slovenia. Twentyfour honeybee colonies, each with ten $41 \mathrm{~cm} \times 26 \mathrm{~cm}$ national standard AZ̆ frames and an average of $6( \pm 2)$ sealed brood, larvae and eggs, were established. All the combs were occupied and each hive was equipped with its own netted bottom-board screen where the dead mites were collected and counted.

The natural mite mortality was monitored four times, between July 8 and August 7, prior to the treatments. The colonies were then divided into three groups and treated for the varroa mites. The nine colonies of group 1 received Apiguard (Vita Europe Ltd., UK), the ten colonies of group 2 received OA, and the five control colonies of group 3 received no treatment until October 2.

The dosages were applied according to the standard application instructions for beekeepers. Apiguard, whose active constituent is thymol and is registered as a control against varroa mites, was applied to group 1 . It is a gelbased product packaged in an aluminium tray. Apiguard coated sheets were placed on the top bars of the frames of each box on August 7 and again on August 21. The space between aluminium try and the hive cover was approximately $4 \mathrm{~cm}$. An oxalic acid/sucrose solution was prepared from $6.5 \mathrm{~g}$ oxalic acid dihydrate (Kemika Zagreb, Croatia) and $50 \mathrm{~g}$ sucrose in $100 \mathrm{ml}$ deionized water. The concentration of OA/sucrose was $2.97 \% / 31.95 \%$ $(\mathrm{w} / \mathrm{w})$. Each colony of group 2 received $50 \mathrm{ml}$ of the $\mathrm{OA} /$ sucrose solution, which was sprinkled between the combs and onto the bees from the top. The first application took place on August 7 and was repeated on August 14 and again on August 21. The colonies of the third group were left untreated until October 2 and so acted as negative controls during the treatment period. Temperatures throughout the treatment period ranged between 19 and $35^{\circ} \mathrm{C}$ in August and between 10 and $24{ }^{\circ} \mathrm{C}$ in September. A Perizin ${ }^{\circledR}$ treatment, with an active ingredient of organophosphate coumaphos, was applied to all the colonies on November 20, when they were without capped brood. This final treatment was performed in order to eliminate the mites from the colonies. Perizin solution was prepared from $10 \mathrm{ml} \mathrm{Perizin}{ }^{\mathbb{B}}$ (Bayer) and approximately $150 \mathrm{~g}$ sucrose in $500 \mathrm{ml}$ water. Each colony received 50 $\mathrm{ml}$ of the solution, which was sprinkled between the combs and onto the bees from the top.

The mite mortality was determined after each treatment. The efficacy of the thymol and OA treatments, expressed in mite mortality, was established after each treatment, and the mite-drop mean values of the treated groups were compared.

The percentage of mites killed by the treatments during the brood periods was estimated by counting the mite "drop-down" after each thymol or OA treatment, and in the broodless period, after the Perizin application.

The following formula was used to estimate the percentage of mites killed (PMK) by the first thymol application (PMKT1) on August 7 (when brood was present):

$\mathrm{PMKT} 1=(\mathrm{T} 1 /(\mathrm{T} 1+\mathrm{T} 2+\mathrm{P}) \times 100) \%$

$\mathrm{T} 1$ and $\mathrm{T} 2$ denote the total number of mites that dropped after the first and second thymol treatments, respectively; and P denotes the number of mites collected after the Perizin treatment on November 20.

The same formula was modified to calculate the percentage of mites that dropped after the second thymol treatment (PMKT2) by excluding the number of mites collected in the first treatment.

The following formula was used to establish the percentage of mites killed (PMK) by the first OA treatment on August 7:

$\mathrm{PMKOA} 1=(\mathrm{OA} 1 /(\mathrm{OA} 1+\mathrm{OA} 2+\mathrm{OA} 3+\mathrm{P}) \times 100) \%$

$\mathrm{OA} 1, \mathrm{OA} 2$ and OA 3 denote the total number of mites that dropped after the first, second and third OA treatments, respectively. The same formula was modified to calculate the percentage of mites that dropped after the second and third OA treatment (PMKOA2, PMKOA3) by excluding the number of mites collected in the preceding treatment or treatments. All the colonies were fed with a sugar solution for overwintering in the period between September 11 and October 2.

The efficacy of a treatment was estimated by comparing the number of mites killed before and after each treatment or any number of consecutive treatments during the experimental period.

During the experiment the colonies were regularly examined to follow their development and to determine if capped brood were present. Data analyses were performed by ANOVA (analysis of variance) with the aid of the Statgraphic programme (1991).

\section{Mite mortality}

\section{Results}

During the 31-day pre-treatment period between July 8 and August 7, the average natural mite mortality per day was $0.23( \pm 0.66)$. No differences in mite mortality levels were found between the groups $(p>0.1)$. In the untreated control colonies of group 3 , the natural 
mortality increased from $0.03( \pm 0.07)$ to $2.67( \pm 4.58)$ before the initial OA treatment on October 2. The natural mite mortality in the period prior to the initial treatments conducted on August 7 and the mortality after each treatment is shown in Fig. 1.

Mite mortality in the Apiguard and OA treated colonies increased significantly $(p<0.001)$ in comparison with the untreated control colonies. A higher mite drop was also observed in the OA treated colonies compared to those receiving the Apiguard $(p<0.01)$ seven days after the OA treatment. The mite drop $(443.45 \pm 524.48)$ after the second application of OA on August 14, remained significantly higher $(p<0.001)$ than that of the Apiguard $(103.88 \pm 167.95)$.

The average mite drop in the 21-day period following the OA application on August 21 was $122.57( \pm 191.03)$, and $42.89( \pm 54.80)$ after the Apiguard application. This difference was statistically significant $(p<0.01)$. During the same period, the average daily mite mortality in the control colonies was $2.28( \pm 2.93)$.

After the colonies of group 3 were treated with three consecutive OA treatments on October 2, 10 and 20, they had an average mite mortality of $1025.83( \pm 229.94)$. The Perizin control-treatment performed on November 20, when the colonies were without brood, resulted in an average mortality of $189.88( \pm 169.76)$ and was significantly higher $(p<0.01)$ in the colonies treated with OA compared to the Apiguard treated colonies.

\section{Mite mortality after treatments}

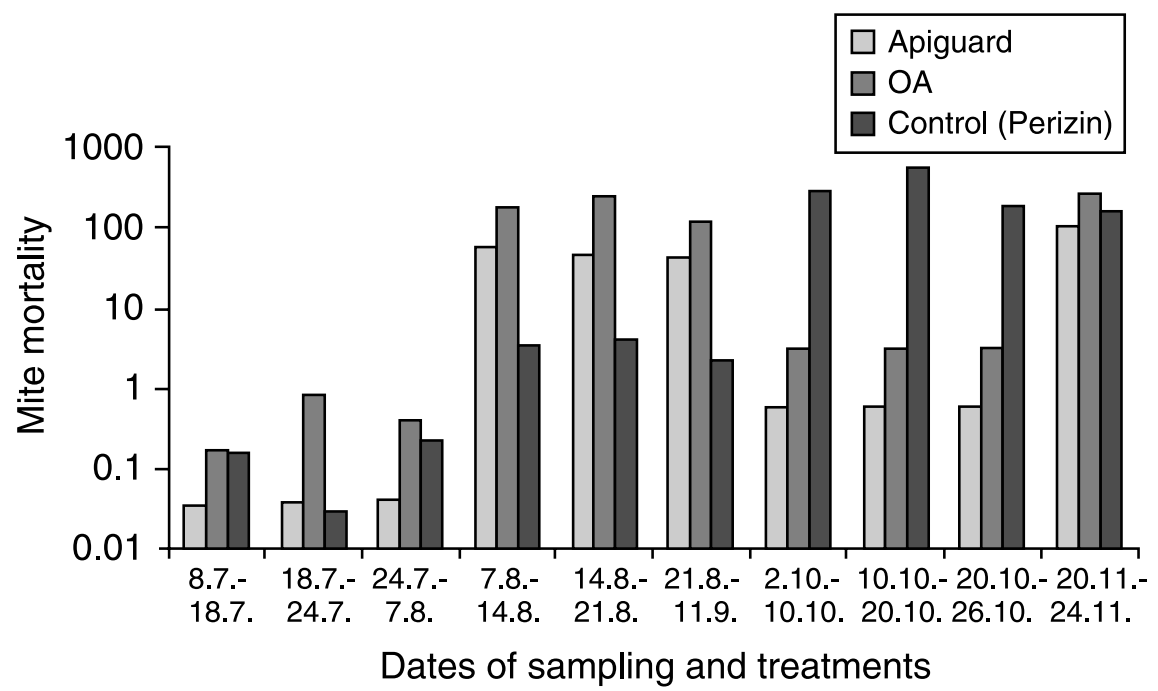

Fig. 1. Mite mortality in the pre-treatment period and after the oxalic acid (OA), Apiguard (A) and control Perizin treatments. Each treatment is indicated by a figure. Apiguard was applied to the colonies on August 7 and 21 and OA was applied on August 7, 14 and 21. A Perizin control was applied on November 20. Control colonies received OA treatments on October 2, 10 and 20. Dead mites were counted on the hives bottom-boards after the treatments. The number of fallen mites is shown on a logarithmic scale.

\section{Efficacy}

The first Apiguard insertions, which occurred on August 7 and remained in the colonies until August 21, resulted in an average mite mortality of $27.63 \%( \pm 20.91)$. The first OA treatment, which was also conducted on the same date, resulted in a mite mortality of $15.47 \%$ $( \pm 9.14)$. The mite mortality triggered by each treatment was significantly higher $(p<0.01)$ 
in comparison with that of the preceding treatment and that of the parallel, untreated controlcolonies. The second OA treatment on August 14 resulted in an 11.64\% $( \pm 13.98)$ mortality rate. The two consecutive OA treatments on August 7 and 14 resulted in a $34.02 \%( \pm 22.11)$ mortality rate, which was higher in comparison with the first Apiguard application though not statistically significant.

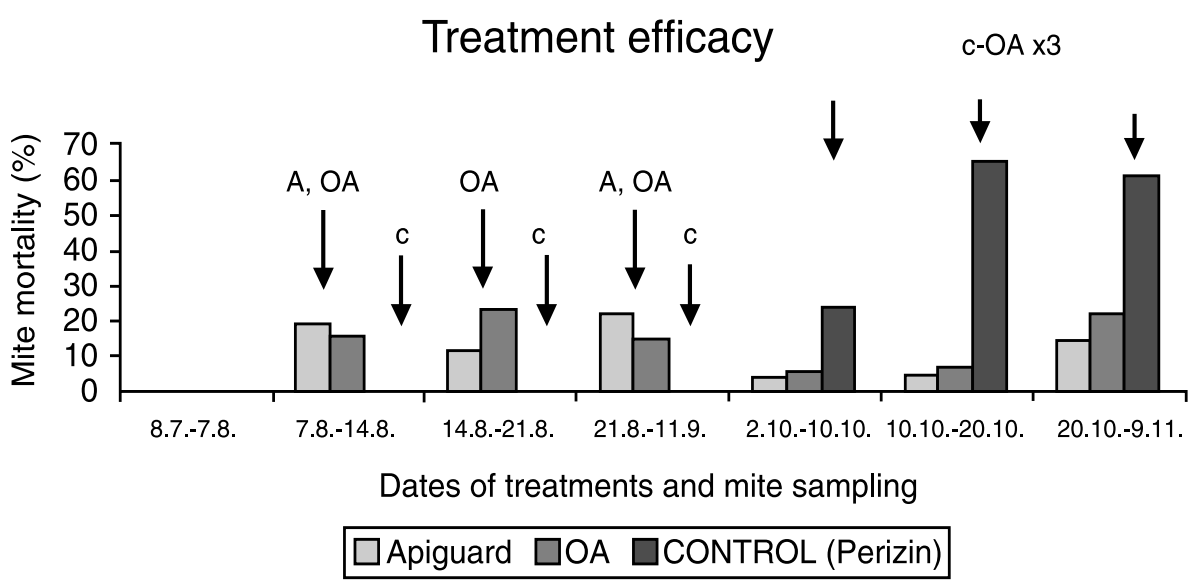

Fig 2. Relative mite mortality in the pre-treatment period and after the Apiguard and OA treatments. Figures show the degree of Apiguard and OA efficacy compared to the control colonies. Varroa mite mortality in the treated colonies was significantly higher than the natural mite mortality in control colonies. After the autumn OA treatments of the previously control colonies their mite mortality increased significantly. Legend: A = Apiguard treatment; $\mathrm{OA}=\mathrm{OA}$ treatment; $\mathrm{c}$ - natural mite mortality in control colonies in a period between 7.8. and 11.9.; $\mathrm{c}-$ $\mathrm{OA} \times 3=$ three OA treatments of the previously control colonies.

The Apiguard and OA applications that took place on August 21 resulted in mortality rates of $22.06 \%( \pm 12.99)$ and $14.77 \%( \pm 14.42)$, respectively. Throughout the treatment period, the mortality rate of the untreated control colonies remained steady and averaged $0.10 \%$ $( \pm 0.08)$. These data are shown in Fig. 2. During the brood period, the cumulative mite mortality of the two Apiguard applications and three OA treatments was $41.98 \%( \pm 21.59)$ and $42.63 \%( \pm 25.22)$, respectively. From October 2 to November 20 mites continued to fall onto the bottom boards. In the previously untreated colonies, the mite drop increased significantly after three OA treatments, as is indicated in Fig. 3, and the cumulative efficacy of the three treatments was $87.92 \%( \pm 12.66)$.

The analyses of variance showed no difference in effectiveness $(p>0.05)$ between the two Apiguard and three OA applications in the period when the brood was present. The effectiveness, expressed as "mite drop down", in all the treated colonies was significantly higher $(p<0.001)$ than in the untreated colonies. Mites continued dropping in the period after the treatments and winter feeding programme, in both the Apiguard- and OA- treated colonies. Although the percentage was higher in the OA colonies the difference was not significant $(p>0.05)$.

During the experiment the development of the colonies was normal. However, during the October OA treatment, the previously untreated colonies had less capped brood in comparison with the other colonies and during the winter of 2003/04 two of the five control colonies collapsed. There were no observable adverse effects on the brood or the adult bees of the Apiguard-treated colonies. 


\section{Cumulative mite mortality}

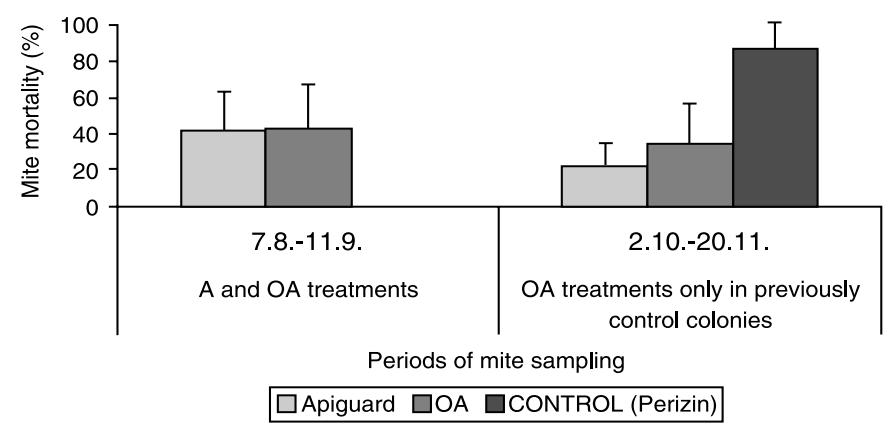

Fig. 3. Comparative cumulative mite mortality following the two Apiguard applications, three OA treatments and control untreated colonies in the period between August 7 and September 11. There was no significant difference in the efficacy of the two treatment methods. Between October 2 and November 20 the previously control colonies were treated three times with OA and had a significantly higher level of mite-drop than the colonies that were no longer receiving treatment. Bars indicate SD.

\section{Discussion}

The increased mite mortality after both the Apiguard and OA treatments in colonies with capped brood, shows the effect of both acaricides against the varroa mite. The efficacy of the first Apiguard gel application in the period between August 7 and August 21 was estimated at $27 \%$ and was $34 \%$ for the two OA treatments given during the same period.

The OA treatments were less effective than the treatments described by Mutinelli et al. (1997) though of the same order found in our previous research (Gregorc and Planinc 2002; Gregorc and Poklukar 2003). After the second Apiguard treatment the total efficacy increased to $42 \%$. The efficacy of the three OA treatments performed during the same period was $43 \%$ and is comparable to the efficacy established by Brødsgaard et al. (1999) after a spring spraying of OA. Trouiller and Watkins (2001) found that the outside temperature had an influence on the release of thymol from its aluminium tray. The efficacy of the treatments is probably underestimated, as the effects that the reproduction of the surviving mites and possible re-invasions may have had were not taken into account.

Mattila and Otis (2000) established mite mortality levels of $76 \%$ and $77 \%$ after applying Apiguard. They also reported a very high natural mortality rate $(23.5 \%)$ in their experimental control colonies. In another of their experiments (1999), they found that, during a 21-day treatment period, Apiguard induced a mite mortality rate that was 4.2 times greater than that of their untreated control colonies. In our experiment, the Apiguard applications produced a mortality rate 7.1 times greater than the natural mortality rate of the untreated colonies. In an experiment conducted in Italy, Colo mbo and Sprea fic o (1999) achieved varroa mite mortality of over $98 \%$ with Apiguard.

Mites continued to fall during the autumn period in both groups 1 (Apiguard) and $2(\mathrm{OA})$, although at a rate significantly lower than that recorded in the control colonies of group 3, which were treated with OA during October. The autumn OA treatments had a higher efficacy than those applied to the colonies with brood (Gregorc and Planinc 2001,2002). However, by the time the Perizin treatment was applied, the mite mortality in the control colonies of group 3 had fallen to the same levels as those of the treated colonies of groups 1 and 2. While the October OA treatments were effective, they were not effective enough for all the colonies to survive the winter. 
The two Apiguard and three OA treatments thus have comparable acaricidal effects during the brood period and their residues pose no risk to the honey (Bogdanov et al. 2002). Both substances, Thymol and OA, which belong to the alternative mite control strategy (Imdorf et al. 2003), could be used successfully, but in practice applying OA is more time consuming than inserting Apiguard into the hive. However, using Apiguard is more intrusive as the aluminium trays need to be both inserted and removed. Both Apiguard and OA could provide beekeepers with an effective alternative for controlling mites during August, particularly in colonies with infestation levels of less than one natural mite-death per day. In Slovenia, an adequate mite control programme could be performed after the main honey flow in June or July, in colonies with mite levels under the economic threshold. Timing the treatment appropriately would ensure that the mite population is reduced to a level that would allow a colony to survive over long winter period experienced on the continent.

\section{Účinnost kyseliny šţavelové a Apiguardu proti varoáze u včelstev včely medonosné (Apis mellifera)}

V experimentu byla srovnávána účinnost roztoku kyseliny štavelové (OA), tvořeného 2,9 \% kyseliny štavelové a 31,9 \% cukru ve vodě a Apiguardu (thymolový gel) při likvidaci včelího roztoče Varroa destructor. Byla sledována mortalita roztočů před a po ošetření. Oproti neošetřeným včelstvům byla u ošetřených Apiguardem či OA signifikantně vyšší $(p<0,001)$. Mortalita roztočů po dvou aplikacích Apiguardu 7. a 21. srpna byla 41,98 \% $( \pm 21,59)$ a po třech aplikacích OA $7 ., 14$. a 21 srpna byla 42,63\% ( $\pm 25,22)$. Všechny aplikace byly provedeny u včelstev s plodem. Další tři aplikace OA provedené během října na dosud neošetřených kontrolních včelstvech vedly k 87,92 \% ( $\pm 12,66)$ mortalitě roztočů. Takováto úroveň likvidace roztočů nebyla dostatečná, aby včelstva přežila zimu. Výsledky ukazují, že OA a Apiguard mají během období růstu včelího plodu pouze omezený účinek. Možnosti využití OA a Apiguardu proti varroáze včelstev jsou v práci diskutovány.

\section{Acknowledgements}

The author would like to thank Borut Preinfalk for his collaboration and technical assistance and Rob Crawford for reading and correcting the manuscript. This work was supported by both the Slovenian Ministry of Education, Science and Sport and the Ministry of Agriculture, Forestry and Food (Research programme P4-0072 and project no. V4-0759-0406-02).

\section{References}

ANDERSON DL, TRUEMAN JWH 2000: Varroa jacobsoni (Acari: Varroidae) is more than one species. Exp Appl Acarol 24: 165-189

BOGDANOV S, KILCHENMANN V, IMDORF A, FLURI P 1998: Residues in honey after application of thymol against Varroa using the Frakno Thymol Frame. Amer Bee J 138: 610-611

BOGDANOV S, CHARRIÈRE JD, IMDORF A, KILCHENMANN V, FLURI P 2002: Determination of residues in honey after treatments with formic and oxalic acid under field conditions. Apidologie 33: 399-409

COLOMBO M, SPREAFICO M 1999: Esperienze di lotta a Varroa jacobsoni Oud. conunnuovoformulato a base di Timolo. La Selezione Veterinaria 7 (July)

BRØDSGAARD CJ, JANSEN SE, HANSEN CW, HANSEN H 1999: Spring treatment with oxalic acid in honeybee colonies as varroa control. DIAS report no. 6 Horticulture, $16 \mathrm{p}$.

FLORIS I, CABRAS P, GARAU VL, MINELLI EV, SATTA A, TROULLIER J 2001: Persistence and effectiveness of pyrethroids in plastic strips against Varroa jacobsoni (Acari: Varroidae) and mite resistance in a Mediterranean area. J Econ Entomol 94: 806-810

GREGORC A, JELENC J 1996: Control of Varroa Jacobsoni Oud. in honeybee colonies using Apilife-Var. Zb Vet Fak Univ Ljubljana 33: 231-235

GREGORC A, PLANINC I 2001: Acaricidal effect of oxalic acid in honeybee (Apis mellifera) colonies. Apidologie 32: 333-340

GREGORC, A, PLANINC, I 2002: The control of Varroa destructor using oxalic acid. Vet J 163: 306-310

GREGORC A, POKLUKAR J 2003: Rotenone and oxalic acid as alternative acaricidial treatments for Varroa destructor in honeybee colonies. Vet Parasitol 111: 351-360 
IMDORF A, BOGDANOV S, IBANEZOCHOA R, CALDERONE N 1999: Use of essential oils for the control of Varroa jacobsoni Oud. in honey bee colonies. Apidologie 30: 209-228

IMDORF A, CHARRIERE JD, KILCHENMANN V, BOGDANOV S, FLURI P 2003: Alternative strategy in central Europe for the control of Varroa destructor in honey bee colonies. Apiacta 38: 258-285

LINDBERG CM, MELATHOPOULOS AP, WINSTON ML 2000: Laboratory evaluation of miticides to control Varroa jacobsoni (Acari: Varroidae), a honey bee (Hymenoptera: Apidae) parasite. J Econ Entomol 93: 189-198

LODESANI M, COLOMBO M, SPREAFICO M 1995: Ineffectiveness of Apistan (R) treatment against the mite Varroa jacobsoni Oud. in several districts of Lombardy (Italy). Apidologie 26: 67-72

MATTILA HR, OTIS GW 2000: The efficacy of Apiguard against varroa and tracheal mites, and its effect on honey production: 1999 trial. Amer Bee J 140: 969-973

MATTILA HR, OTIS GW 1999: Trials of Apiguard, a thymol-based miticide. Part 1. Efficacy for control of parasitic mites and residues in honey. Amer Bee J 139: 947-952

MILANI N 1999: The resistance of Varroa jacobsoni Oud to acaricides. Apidologie 30: 229-234

MIOZES-KOCH R, SLABEZKI Y, EFRAT H, KALEV H, KAMER Y, YAKOBSON DA 2000: First detection in Israel of fluvalinate resistance in the varroa mite using bioassay and biochemical methods. Exp Appl Acarol 24: 35-43

MUTINELLI F, BAGGIO A, CAPOLONGO F, PIRO R, PRANDIN L, BIASION L 1997: A scientific note on oxalic acid by topical application for the control of varroosis. Apidologie 28: 461-462

NANETTI A, MASSI A, MUTINELLI F, CREMASCO S 1995: L'acido ossalico nel controllo della varroasi: note preliminary. Apitalia 22: 29-32

Statgraphics, Statistical graphic system, STSC, Rockville 1991.

TROUILLER J, WATKINS M 2001: Experimentation on Apiguard - a controlled release gel of thymol against honeybee diseases. In: Proceedings of the 37th International Apicultural Congress, 28 October - 1 November 2001, Durban, South Africa, APIMONDIA2001, Document Transformation Technologies

WALLNER K 1999: Varroacides and their residues in bee products. Apidologie 30: 235-248 